\title{
Ciprofloxacin Residue in Marketed Pork of North-East
}

\section{India}

\author{
D. C. Roy, A. Kafle, S. K. Laskar and R. K. Roy \\ Department of Pharmacology and Toxicology, College of Veterinary Science, A.A.U., Khanapara, Guwahati 781022, Assam, India
}

\begin{abstract}
Background: Ciprofloxacin is commonly indicated for treating bacterial infections in dogs and cats and is generally not recommended for large animals like pig. Enrofloxacin on the other hand is specially developed for veterinary use (small and large animals), however the main metabolite of enrofloxacin is ciprofloxacin and the data of ciprofloxacin residue in pork are limited. Objective: To evaluate the residue of ciprofloxacin in pork samples obtained from four different states namely Assam, Nagaland, Manipur and Mizoram of North-East India. Method: 720 samples comprising of Liver, Kidney, and Muscle were collected in clear sterile container and transported to the laboratory in ice packs. The samples were kept at $-20{ }^{\circ} \mathrm{C}$ till analysis. Ultra High Performance Chromatography (UHPLC) equipped with Diode Array Detector (DAD) was used for screening the samples. Level of detection was $0.001 \mu / \mathrm{g}$. Result: Out of 720 samples, 49 samples were found with detectable level of ciprofloxacin residue however none of the residue levels were above the permissible limit (Maximum Residue Limit). Conclusion and Public Health Importance: This study clearly proved that although the residue has been detected in the marketed pork samples the levels of residue were below the permissible limit hence the pork obtained from these states is safe from public health point of view.
\end{abstract}

Key words: Antibiotics, ciprofloxacin, pig, residue, UHPLC.

\section{Introduction}

Antibiotics have achieved higher attention in clinical cases regardless of the species; be it a human or animal. Any sort of bacterial infection needs to be treated with antibiotics either locally or parenterally. India is an agriculture based country with livestock being the major source of income for rural youth. Antibiotics have been used increasingly for treatment of bacterial diseases and moreover they are important in animal husbandry because they significantly enhance growth when added to animal feed, although European Union (EU) legislation has forbidden this practice since 2006 [1]. Fluorquinolones form a group of synthetic drug extensively used in human and animal medicines to combat infections caused by both gram positive and gram negative bacteria [2]. There is a concern that the frequent use of enrofloxacin or its

Corresponding author: Dr. D. C. Roy, M. V. Sc, PhD, F.A.Sc, D. Litt, Prof cum PI, research fields: pharmacology and toxicology. active metabolite ciprofloxacin has been associated with increased residue in meat meant for human consumption. This residue may results in drug allergy and drug resistance [3]. In a study it was found that $77 \%$ of consumers are responding to animal drug residues in meats. Enrofloxacin (ENR) is a common bacteriostatic and bactericidal drug, whose chemical name is 1-cyclopropyl -6-fluoro-4-oxygenation 1 , 4-dihydrogen-7-(4-ethyl-1-piperazinyl)-3-quinoline carboxylic acid. Ciprofloxacin (CIP) is its metabolite, and its antibacterial activity is stronger than ENR. Both of them are the 3rd generation antibiotics of quinolones.

Enrofloxacin is dealkylated to pharmacologically active metabolite ciprofloxacin, a is available as a separate medication and is a broad-spectrum antimicrobial carboxyfluoroquinoline [4-6]. Based on the results published, the residue of ciprofloxacin in pork in India is limited so an effort has been made to study the same in the present study. 


\section{Materials and Methods}

\subsection{Chemical and Reagents}

Ciprofloxacin standard (sigma aldrich), HPLC grade Acetonitrile (Fisher Scientific), Methanol (Fisher Scientific) and HPLC grade water (Fisher Scientific) were used for the study.

\subsection{Sample Collection}

A total of 720 samples of pork were collected from local vendors of Assam, Nagaland, Manipur and Mizoram for analysis. The samples were collected aseptically in a clean sterile container and were transported to the laboratory in ice packs and preserved at $-20{ }^{\circ} \mathrm{C}$ till analysis.

\subsection{Chromatographic Conditions}

The levels of ciprofloxacin were determined using a
UHPLC system (Make: Dionex) equipped with an autosampler and Diode Array Detector (DAD) operated at $277 \mathrm{~nm}$ (excitation) and $450 \mathrm{~nm}$ (emission) at ambient temperature. The samples were separated on an RP-C 18 column and were eluted with a mobile phase of a mixture of water and acetonitrile in the ration of $67: 33 \mathrm{v} / \mathrm{v}$. The isocratic mode was run at a flow rate of $1.0 \mathrm{~mL} / \mathrm{min}$ with Coefficient of Determination of STD curve $99.0 \%$. Further the Limit of Detection (LOD) and Limit of Quantification (LOQ) were $0.001 \mu \mathrm{g} / \mathrm{g}$ and $0.004 \mu \mathrm{g} / \mathrm{g}$ respectively. The repeatability percentage was $86.0-97.0 \%$. Fig. 1 and Fig. 2 represent the standard and test curve of ciprofloxacin respectively.

\subsection{Preparation of Samples}

The fascia and fat of pork samples were removed and then cut into small pieces. $10 \mathrm{~g}$ of each sample

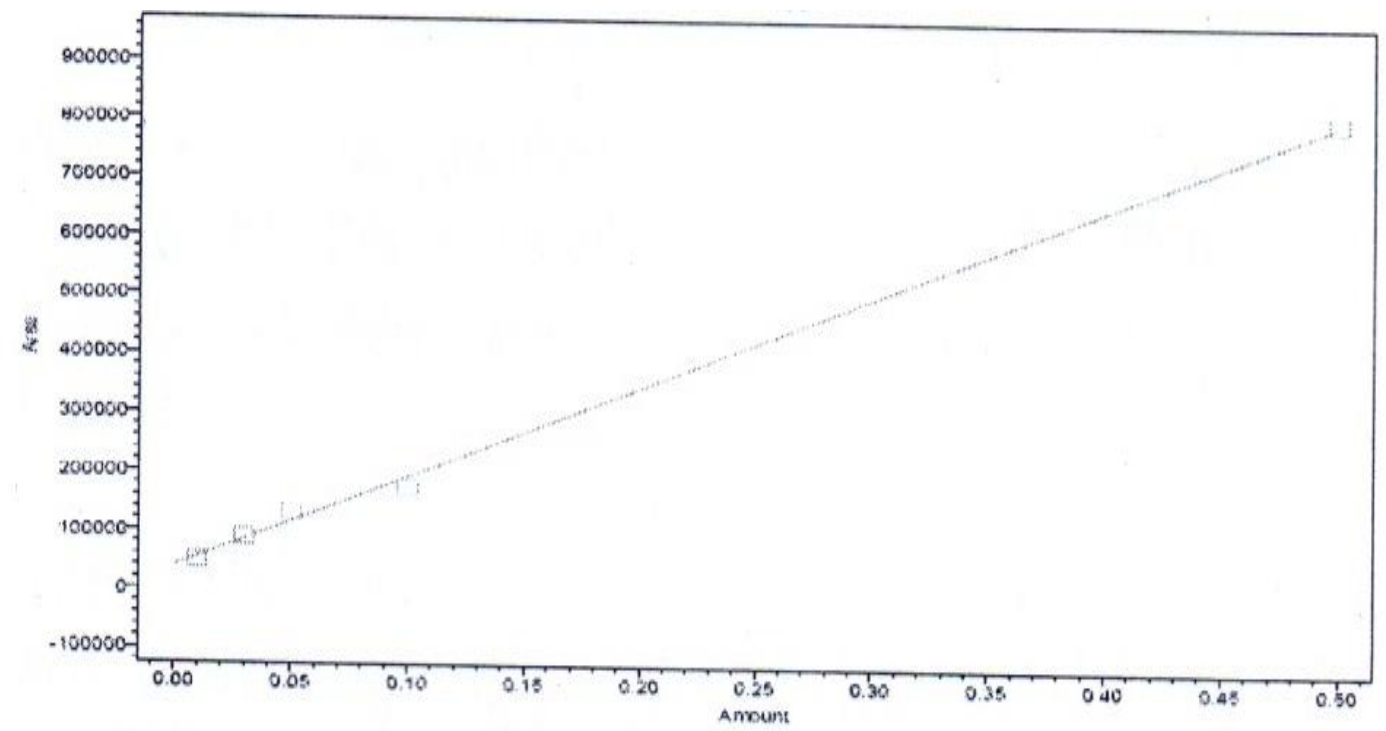

\begin{tabular}{|c|c|c|c|c|c|c|c|c|}
\hline & Nanve & Lovel & & & & & & \\
\hline 1 & & & & & & o Deviation & Manual & gnoro \\
\hline 2 & & & 010000 & 40316.719456 & 0.006801 & -31.057 & No & No \\
\hline & Catronby acen & & 0,070000 & 89748.0986001 & 0.093432 & 10.441 & No & No \\
\hline & copotbosain & & 0.050000 & 131531.304642 & 0.080410 & 20.820 & No & No \\
\hline 4 & Coprofkoxacin & & 0.100000 & 174802.182318 & 0.023527 & -11.473 & No & No \\
\hline 5 & Ouprofkay ac in & & 0.500000 & $806324.27 A 19 A$ & 0.503130 & 0.226 & No & No \\
\hline
\end{tabular}

Reported by User: System

Report Method: Untitied

Report Method 10100

Page: 1 of 1
Project Name DefaultsiPHARMACOLOGY

Date Printed:

$7 / 12 / 2011$

Fig. 1 Calibration curve of ciprofloxacin standard. 


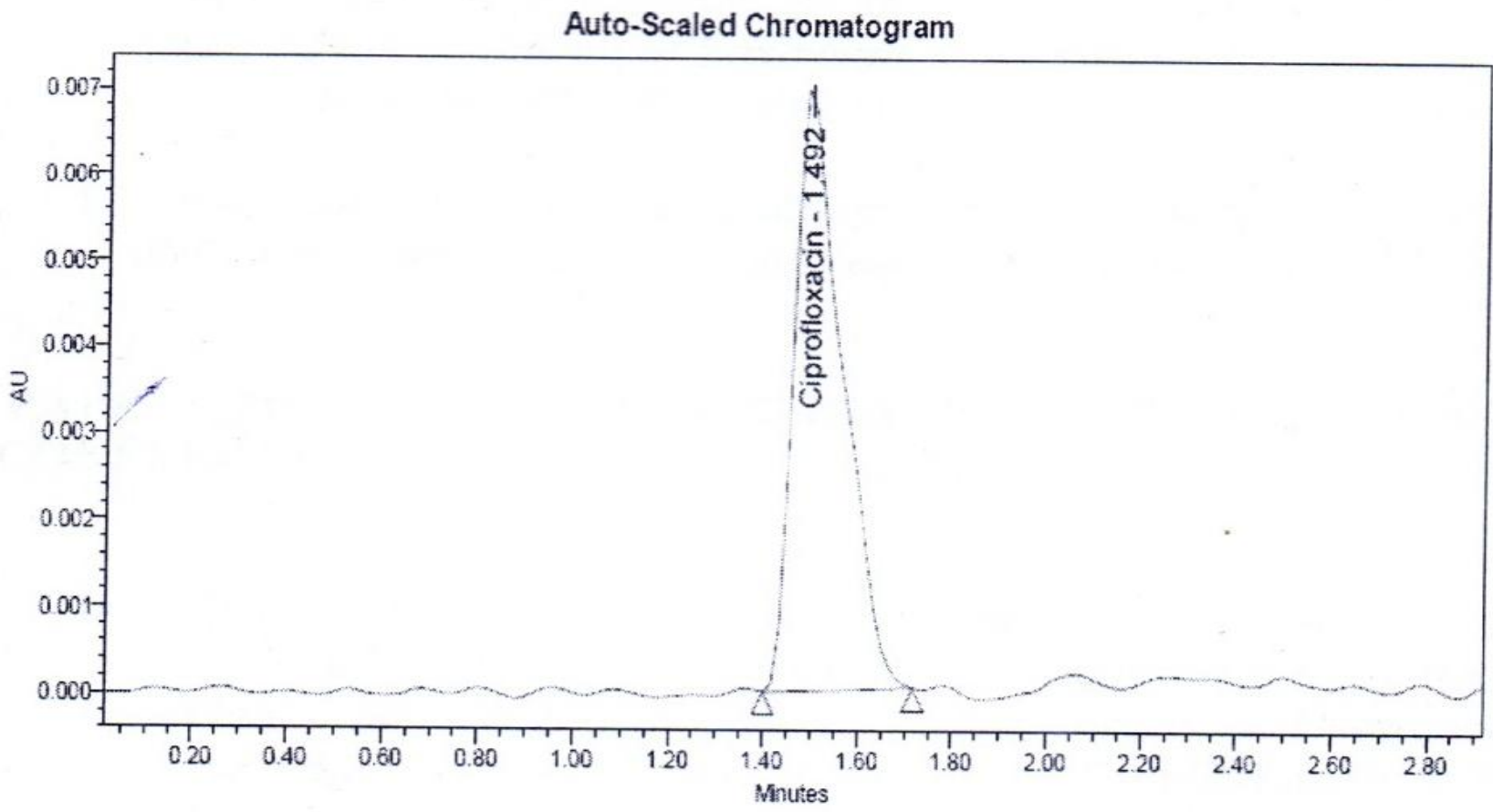

Fig. 2 Chromatogram of pork muscle sample detecting ciprofloxacin residue.

was taken in a blender and to it added an equal volume of distilled water. $10 \mathrm{~g}$ of each blended sample was transferred to a centrifuge tube. After a few minutes $10 \mathrm{~mL}$ of acetonitrile was added. The sample was ultrasonicated and left undisturbed for $10 \mathrm{~min}$. The samples were centrifuged and the collected supernatant was filtered. The filtrate was then passed through $\mathrm{C} 18$ polymeric cartridge after which it was further filtered using 0.22 um filter paper.

\section{Result}

The level of Ciprofloxacin residue in the states of Assam, Nagaland, Manipur and Mizoram has been presented in Table 1, Table 2, Table 3 and Table 4, respectively.

\section{Discussion}

In majority of the samples tested, the level of ciprofloxacin residue was found to be highest in Kidney followed by Liver and muscle. Ciprofloxacin is primarily eliminated via urinary route and very less (15\%) accounts for faecal excretion following an intravenous infusion [7]. The drug is partially metabolized in the liver by modification of the piperazinyl group to four metabolite namely, desethyleneciprofloxacin, sulfo-ciprofloxacin, oxo-ciprofloxacin, and $\mathrm{N}$-acetylciprofloxacin, oxo-ciprofloxacin being the major urinary metabolite, and sulfo-ciprofloxacin the primary faecal metabolite. Ciprofloxacin and its metabolites are excreted in urine by both glomerular filtration and by tubular secretion [8]. The results are in close agreement [9] that showed that ciprofloxacin residual concentration is more in liver and kidney as compared to muscle tissues of poultry. In a study it was shown that over $80 \%$ of the pork samples were found to contain enrofloxacin and ciprofloxacin residue [10].

Residues have been reported in $21 \%$ of meat samples in Ghana [11], and 70\% in Tanzania [12]. Other authors [13] had also found that that more than $50 \%$ of poultry meat tissues tested in Iran had residues of antimicrobials.

However, the present findings differ from the observations of authors [14] who found that ciprofloxacin residual concentration is more in muscle as compared to kidney and liver of poultry. The present 
Table 1 Ciprofloxacin Residue in Marketed Pork of Assam.

\begin{tabular}{|c|c|c|c|c|c|c|c|}
\hline \multicolumn{8}{|l|}{ Region: Assam } \\
\hline $\begin{array}{l}\text { Name of the } \\
\text { residue/toxic metal } \\
\text { analysed }\end{array}$ & Sample & $\begin{array}{l}\text { No. of } \\
\text { samples } \\
\text { analysed }\end{array}$ & $\begin{array}{l}\text { No. of }+ \\
\text { samples }\end{array}$ & $\begin{array}{l}\text { Range conc. } \\
\text { (ug/g) }\end{array}$ & $\begin{array}{l}\text { No. of }+ \\
\text { samples above } \\
\text { MRL/MPL }\end{array}$ & $\begin{array}{l}\text { Mean conc. of } \\
\text { samples which } \\
\text { are above } \\
\text { MRL/MPL }\end{array}$ & $\begin{array}{l}\text { Approved MRL/MPL } \\
\text { Ug/g } \\
\text { As per Codex } \\
\text { Alimnetarius }\end{array}$ \\
\hline \multirow{3}{*}{ Cirprofloxacin } & Kidney & 63 & 7 & $0.019-0.280$ & ND & ND & 0.3 \\
\hline & Liver & 64 & 5 & $0.016-0.128$ & ND & ND & 0.2 \\
\hline & Muscle & 65 & 4 & $0.004-0.071$ & ND & ND & 0.1 \\
\hline
\end{tabular}

Table 2 Ciprofloxacin Residue in Marketed Pork of Nagaland.

\begin{tabular}{|c|c|c|c|c|c|c|c|}
\hline \multicolumn{8}{|l|}{ Region: Nagaland } \\
\hline $\begin{array}{l}\text { Name of the } \\
\text { residue/toxic metal } \\
\text { analysed }\end{array}$ & Sample & $\begin{array}{l}\text { No. of } \\
\text { samples } \\
\text { analysed }\end{array}$ & $\begin{array}{l}\text { No. of + } \\
\text { samples }\end{array}$ & $\begin{array}{l}\text { Range conc. } \\
(\mathrm{ug} / \mathrm{g})\end{array}$ & $\begin{array}{l}\text { No. of }+ \\
\text { samples above } \\
\text { MRL/MPL }\end{array}$ & $\begin{array}{l}\text { Mean conc. of } \\
\text { samples which } \\
\text { are above } \\
\text { MRL/MPL }\end{array}$ & $\begin{array}{l}\text { Approved } \\
\text { MRL/MPL } \\
\mu \mathrm{g} / \mathrm{g} \\
\text { As per Codex } \\
\text { Alimnetarius }\end{array}$ \\
\hline \multirow{3}{*}{ Cirprofloxacin } & Kidney & 67 & 4 & $0.093-0.185$ & ND & ND & 0.3 \\
\hline & Liver & 61 & 6 & $0.062-0.154$ & ND & ND & 0.2 \\
\hline & Muscle & 58 & 3 & $0.020-0.065$ & ND & ND & 0.1 \\
\hline
\end{tabular}

Table 3 Ciprofloxacin Residue in Marketed Pork of Manipur.

\begin{tabular}{|c|c|c|c|c|c|c|c|}
\hline \multicolumn{8}{|l|}{ Region: Manipur } \\
\hline $\begin{array}{l}\text { Name of the } \\
\text { residue/toxic metal } \\
\text { analysed }\end{array}$ & Sample & $\begin{array}{l}\text { No. of } \\
\text { samples } \\
\text { analysed }\end{array}$ & $\begin{array}{l}\text { No. of + } \\
\text { samples }\end{array}$ & $\begin{array}{l}\text { Range conc. } \\
(\mathrm{ug} / \mathrm{g})\end{array}$ & $\begin{array}{l}\text { No. of }+ \\
\text { samples above } \\
\text { MRL/MPL }\end{array}$ & $\begin{array}{l}\text { Mean conc. of } \\
\text { samples which } \\
\text { are above } \\
\text { MRL/MPL }\end{array}$ & $\begin{array}{l}\text { Approved } \\
\text { MRL/MPL } \\
\text { Ug/g } \\
\text { As per Codex } \\
\text { Alimnetarius }\end{array}$ \\
\hline \multirow{3}{*}{ Cirprofloxacin } & Kidney & 60 & 5 & $0.012-0.287$ & ND & ND & 0.3 \\
\hline & Liver & 60 & 3 & $0.048-0.108$ & ND & ND & 0.2 \\
\hline & Muscle & 60 & 2 & $0.024-0.055$ & ND & ND & 0.1 \\
\hline
\end{tabular}

Table 4 Ciprofloxacin Residue in Marketed Pork of Mizoram.

\begin{tabular}{|c|c|c|c|c|c|c|c|}
\hline \multicolumn{8}{|l|}{ Region: Mizoram } \\
\hline $\begin{array}{l}\text { Name of the } \\
\text { residue/toxic metal } \\
\text { analysed }\end{array}$ & Sample & $\begin{array}{l}\text { No. of } \\
\text { samples } \\
\text { analysed }\end{array}$ & $\begin{array}{l}\text { No. of + } \\
\text { samples }\end{array}$ & $\begin{array}{l}\text { Range conc. } \\
(\mathrm{ug} / \mathrm{g})\end{array}$ & $\begin{array}{l}\text { No. of }+ \\
\text { samples above } \\
\text { MRL/MPL }\end{array}$ & $\begin{array}{l}\text { Mean conc. of } \\
\text { samples which } \\
\text { are above } \\
\text { MRL/MPL }\end{array}$ & $\begin{array}{l}\text { Approved } \\
\text { MRL/MPL } \\
\text { Ug/g } \\
\text { As per Codex } \\
\text { Alimnetarius }\end{array}$ \\
\hline \multirow{3}{*}{ Cirprofloxacin } & Kidney & 54 & 5 & $0.014-0.280$ & ND & ND & 0.3 \\
\hline & Liver & 54 & 2 & $0.050-0.120$ & ND & ND & 0.2 \\
\hline & Muscle & 54 & 3 & $0.024-0.052$ & ND & ND & 0.1 \\
\hline
\end{tabular}

authors [15] also reported similar findings with 36 out of 586 pork samples were found to be positive for enrofloxacin residues.

\section{Conclusions}

Ciprofloxacin though rarely used for the treatment of large animals but it is the active metabolite of enrofloxacin which is specially developed for veterinary use. The drug has a tendency to accumulate in the kidney to greater extent followed by liver and muscle of pigs. The present study showed that although the level of ciprofloxacin was detected in all the samples, none of the values were above the permissible limit $(0.1-0.3 \mu \mathrm{g} / \mathrm{g})$. The findings could be due to proper enforcement and implementation of withdrawal period. However, close monitoring of the 
same should be carried out to safeguard public health in near future.

\section{Conflict of Interest}

None.

\section{Acknowledgement}

The authors are grateful to ICAR and AAU for providing financial help and technical support.

\section{References}

[1] Currie, D., Lynas, L., Kennedy, D. G., and McCaughey, W. J. 1998. "Evaluation of a Modified EC Four Plate Method to Detect Antimicrobial Drugs." Food Addit. Contam 15: 651-60.

[2] Resurreccion, A. V. A., and Galvez, F. 1999. "Will Consumers Buy Irradiated Beef?" Food Technol 53: 52-5.

[3] Vance-Bryan, K., Guay, D. R., and Rotschafer, J. C. 1990. "Clinical Pharmacokinetics of Ciprofloxacin." Clin Pharmacokinetics 19 (6): 434-61.

[4] Jensen, U. S., Muller, A., and Brandt, C. T. 2010. "Effect of Generics on Price and Consumption of Ciprofloxacin in Primary Healthcare: The Relationship to Increasing Resistance." J Antimicrob Chemother 65: 1286-91.

[5] Xu, W., Zhu, X., Wang, X., Liping, D., and Gan, Z. 2006. "Residues of Enrofloxacin, Furazolidone and Their Metabolites in Nile Tilapia (Oreochromis niloticus)." Aquaculture 254: 1-8.

[6] Fang, W., Zhou, S., and Yu, H. 2007. "Pharmacokinetics and Tissue Distribution of Enrofloxacin and Its Metabolite Ciprofloxacin in Scylla Serrata Following Oral Gavage at Two Salinities." Aquaculture 272: 180-7.
[7] Xu, L., Wang, H., Yang, X., and Lu, L. 2013. "Integrated Pharmacokinetics/Pharmacodynamics Parameters Based Dosing Guidelines of Enrofloxacin in Grass Carp Ctenopharyngodon Idella to Minimize Selection of Drug Resistance." BMC Vet. Res 9: 126.

[8] Al-Omar, M. 2005. "Ciprofloxacin: Drug Metabolism and Pharmacokinetic Profile." Profiles of Drug Substances, Excipients and Related Methodology 31: 209-214.

[9] Kurwijila, L. R., Omore, A., Staal, S., and Mdoe, N. S. 2006. "Investigation of the Risk of Exposure to Antimicrobial Residues Present in Marketed Milk in Tanzania." Journal of Food Protection 69 (10): 2487-92.

[10] Ramos, M. Aranda, A., Garcia, E., Reuvers, T., and Hooghuis, H. 2003. "Simple and Sensitive Determination of Five Quinolones in Food by Liquid Chromatography with Fluorescence Detection." J. Chromatogr. B 789: 373-81.

[11] Novais, A., Comas, I., Baquero, F., Canton, R., Coque, T. M., Moya, A., Gonzalez-Candelas, F., and Galan, J. C. 2010. "Evolutionary Trajectories of Beta-lactamase CTX-M-1 Cluster Enzymes: Predicting Antibiotic Resistance." PLoS Pathogens 6 (1): 22-9.

[12] Kurwijila, L. R., Omore, A., Staal, S., and Mdoe, N. S. 2006. "Investigation of the Risk of Exposure to Antimicrobial Residues Present in Marketed Milk in Tanzania." Journal of Food Protection 69 (10): 2487-92.

[13] Tajick, M. A., and Shohreh, B. 2006. "Detection of Antibiotics Residue in Chicken Meat Using TLC." International Journal of Poultry Science 5 (7): 611-2.

[14] Turnidge, J. 2004. "Antibiotic use in Animals-Prejudices, Perceptions and Realities." The Journal of Antimicrobial Chemotherapy 53: 26-7.

[15] Roy, D. C., Gogoi, R., and Laskar, S. K. 2017. "Enrofloxacin Residue Detection in Marketed Pork of North East India." Int. J. Livest. Res 7 (5): 256-60. 